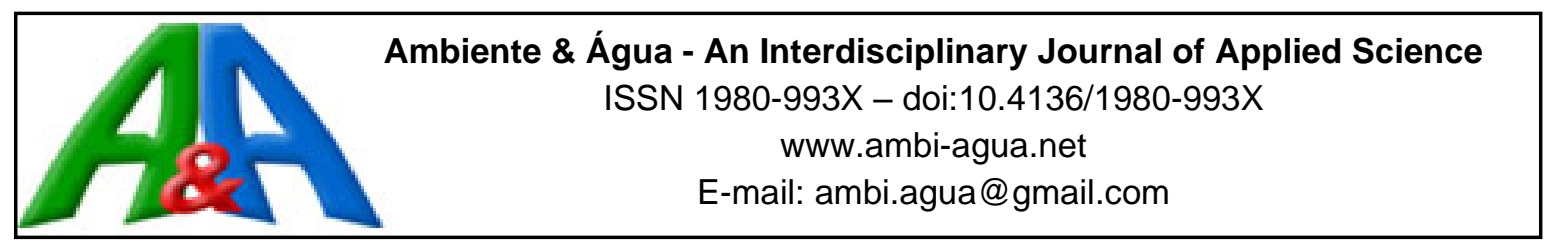

\title{
Sorption of the Direct Black 22 dye in alluvial soil
}

\author{
ARTICLES doi:10.4136/ambi-agua.2483
}

Received: 06 Oct. 2019; Accepted: 08 Jun. 2020

\begin{abstract}
Jeisiane Isabella da Silva Alexandre ${ }^{1(D)}$; Severino Martins dos Santos Neto ${ }^{2 *}$; Artur Paiva Coutinho' ${ }^{(D}$; Tássia dos Anjos Tenório de Melo ${ }^{3}$; Elizabeth Amaral Pastich Gonçalves1 ${ }^{1 D}$; Manuella Virginia Salgueiro Gondim² ${ }^{\text {D }}$; Antonio Celso Dantas Antonino' ${ }^{2}$; Ana Emília Carvalho de Gusmão da Cunha Rabelo ${ }^{2}$; ; Aline Lima de Oliveira $^{2}[D$

${ }^{1}$ Núcleo de Tecnologia. Universidade Federal de Pernambuco (UFPE), Avenida Marielle Franco, S/N, CEP: 55014-900, Km 59, Caruaru, PE, Brazil. E-mail: jeisianebellas150@ hotmail.com, arthur.coutinho@yahoo.com.br, bethpastich@yahoo.com.br

${ }^{2}$ Departamento de Energia Nuclear. Universidade Federal de Pernambuco (UFPE), Avenida Luiz Freire, $n^{\circ} 1000$, CEP: 50740-545, Recife, PE, Brazil. E-mail: manuellavirginia@yahoo.com.br, acdantonino@gmail.com, anaerabelo@gmail.com, alinelimadeoliveira.alo@gmail.com

${ }^{3}$ Departamento de Arquitetura e Urbanismo. Universidade Federal de Pernambuco (UFPE), Avenida Acadêmico Hélio Ramos, S/N, CEP: 50740-540, Recife, PE, Brazil. E-mail: melo.tassia@yahoo.com.br

*Corresponding author. E-mail: martinsdsn@gmail.com
\end{abstract}

\begin{abstract}
The semiarid region of Pernambuco has a large water deficit, leading the population to explore groundwater resources such as alluvial aquifers. The state of Pernambuco also stands out for having the second-largest textile manufacturing center in Brazil. However, the direct discharge of textile effluents from the region's industries has intensified the negative impacts on water conservation and alluvial soils. This work characterized the sorption of Direct Black 22 dye (DB22) in two layers of alluvial soil in the Capibaribe-PE basin. Batch experiments (kinetics and sorption isotherms) allowed the evaluation of the retention potential and mobility of this compound in this environment. Sorption kinetics were verified for stirring times of 0.25 ; $0.5 ; 1 ; 2 ; 4 ; 6 ; 8 ; 10 ; 12 ; 24 ; 48$ and 72 hours and the experimental data was adjusted to the firstand second-order kinetic models. The isotherm occurred with concentrations of $1 ; 5 ; 10 ; 15$; 20; 32.5 and $40 \mathrm{mg} . \mathrm{L}^{-1}$ and experimental data was adjusted to the linear, Freundlich and Langmuir models. The sorption kinetics of DB22 was best described by the second-order model, while the Freundlich and Linear models properly fitted sorption isotherms for Layers 1 and 2. The organic matter contents and the cation-exchange capacity of the soil layers influenced the sorption of the dye. The superficial layer privileges dye retention phenomena, while in the subsurface layer dye mobility phenomena prevail.
\end{abstract}

Keywords: contamination, emerging pollutants, groundwater, isotherms, semiarid, wastewater.

\section{Sorção do corante têxtil Direct Black 22 em solo aluvionar}

\section{RESUMO}

O semiárido pernambucano é uma região que apresenta grande déficit hídrico, levando a população a explorar os recursos hídricos subterrâneos como os aquíferos aluvionares. O estado de Pernambuco também se destaca por conter o segundo maior polo de confecções têxteis do 
Brasil. No entanto, o lançamento direto de efluentes têxteis provenientes das indústrias da região tem intensificado os impactos negativos na conservação da água e dos solos aluvionares. O objetivo deste trabalho consiste na caracterização da sorção do corante Direct Black 22 (DB22) em solos de duas camadas de um aluvião na bacia do Capibaribe-PE. Os ensaios de Bacth (cinética e isotermas de sorção) permitiram avaliar o potencial de retenção e mobilidade desse composto nesse ambiente. A cinética de sorção foi verificada com os tempos de agitação de 0,$25 ; 0,5 ; 1 ; 2 ; 4 ; 6 ; 8 ; 10 ; 12 ; 24 ; 48$ e 72 horas e os dados experimentais foram ajustados aos modelos cinéticos de primeira e segunda. A isoterma ocorreu com concentrações de $1 ; 5$; $10 ; 15 ; 20 ; 32,5$ e $40 \mathrm{mg} . \mathrm{L}^{-1}$, e os dados experimentais foram ajustados ao modelo linear, de Freundlich e de Langmuir. A cinética de sorção do DB22 foi melhor descrita pelo modelo de segunda ordem e as isotermas de sorção para Camadas 1 e 2 ajustaram-se adequadamente aos modelos de Freundlich e Linear. Os teores de matéria orgânica e a capacidade de troca catiônica das camadas de solo foram propriedades que influenciaram na sorção do corante. A camada superficial privilegia fenômenos de retenção do corante enquanto que a camada subsuperficial privilegia fenômenos de mobilidade do corante.

Palavras-chave: águas residuais, águas subterrâneas, contaminação, isotermas, poluentes emergentes, semiárido.

\section{INTRODUCTION}

Water availability in quantity and quality for multiple uses is an inherent concern of the population living in semiarid regions in northeastern Brazil. However, despite this problem, part of this region stands out as the second-largest textile manufacturing center in Brazil. The Pernambuco municipalities of Caruaru, Toritama, and Santa Cruz do Capibaribe are the main cities of this textile hub (Oliveira and Braga, 2014).

Alluvial deposits are geological formations that commonly occupy the beds of temporary rivers in the northeastern semiarid region. These deposits act as natural water reservoirs, allowing water supply during critical scarcity periods (Brito et al., 2018). Despite being an essential water supply source, these formations are the destination of indiscriminate wastewater disposal by the region's textile industries. This considerably raises the risk of environmental contamination, as the release of textile effluents promotes the entry of various pollutants into the environment (Ali et al., 2009; Shehzadi et al., 2014; Konicki et al. 2017). For example, Shalaby et al. (2016) point out that the wastewater from these industries is a complex mixture of dyes and heavy metal compounds, and Vikrant et al. (2018) highlighted that $15 \%$ of the dyes are lost in effluents during the dyeing process.

Among the materials used by the textile industries, dyes, which are emerging pollutants, offer a high possibility of environmental contamination (Montagner et al., 2017), being potentially hazardous for both the environment and human health (Munagapati et al., 2019; Nazir et al., 2020), even at low concentrations. There is also a lack of legislation to regulate their maximum allowable concentration in effluents (Souza and Souza, 2016). Therefore, to enable the development of studies concerning the analysis of groundwater vulnerability and conservation of its quality, it is fundamental to assess retention capacity and mobility of dyes in soils of alluvial deposits (Qu et al., 2008; Dawodu and Akpomie, 2016; Silva Júnior et al., 2019; Alves et al., 2020).

Furthermore, Direct Black 22 (DB22), which is an azo dye characterized by the presence of the double bond between two nitrogen atoms $(-\mathrm{N}=\mathrm{N}-)$ (Graciani, 2014), stands out as one of the most-used dyes among the textile industries of Pernambuco's Agreste (Amorim et al., 2013). Investigations regarding the behavior of azo dyes, such as DB22 in alluvial deposits of the Capibaribe watershed, are still minimal. Therefore, considering these facts, this research 
evaluated DB22 sorption through sorption kinetics and isotherm experiments in two soil layers of an alluvial deposit of Pernambuco semiarid region.

\section{MATERIALS AND METHODS}

\subsection{Study Area}

The study area is located in the Poço da Lama Ranch in the city of Brejo da Madre de Deus, bordering the city of Santa Cruz do Capibaribe in Pernambuco's State, Brazil (Figure 1). Soil samples were taken from the dry bed of the Capibaribe River, which is formed by a deposit of alluvial sediments. The aquifer in this area is widely exploited as a source of groundwater resources. The region has an average rainfall of $600 \mathrm{~mm} /$ year and potential evapotranspiration of $1900 \mathrm{~mm} /$ year, with semiarid climatic conditions and native vegetation cover of Caatinga (Braga et al., 2015). Geologically, the study area is located in the Borborema Province, with crystalline rocky features and hydrogeology of fissural domain (Beltrão et al., 2005).

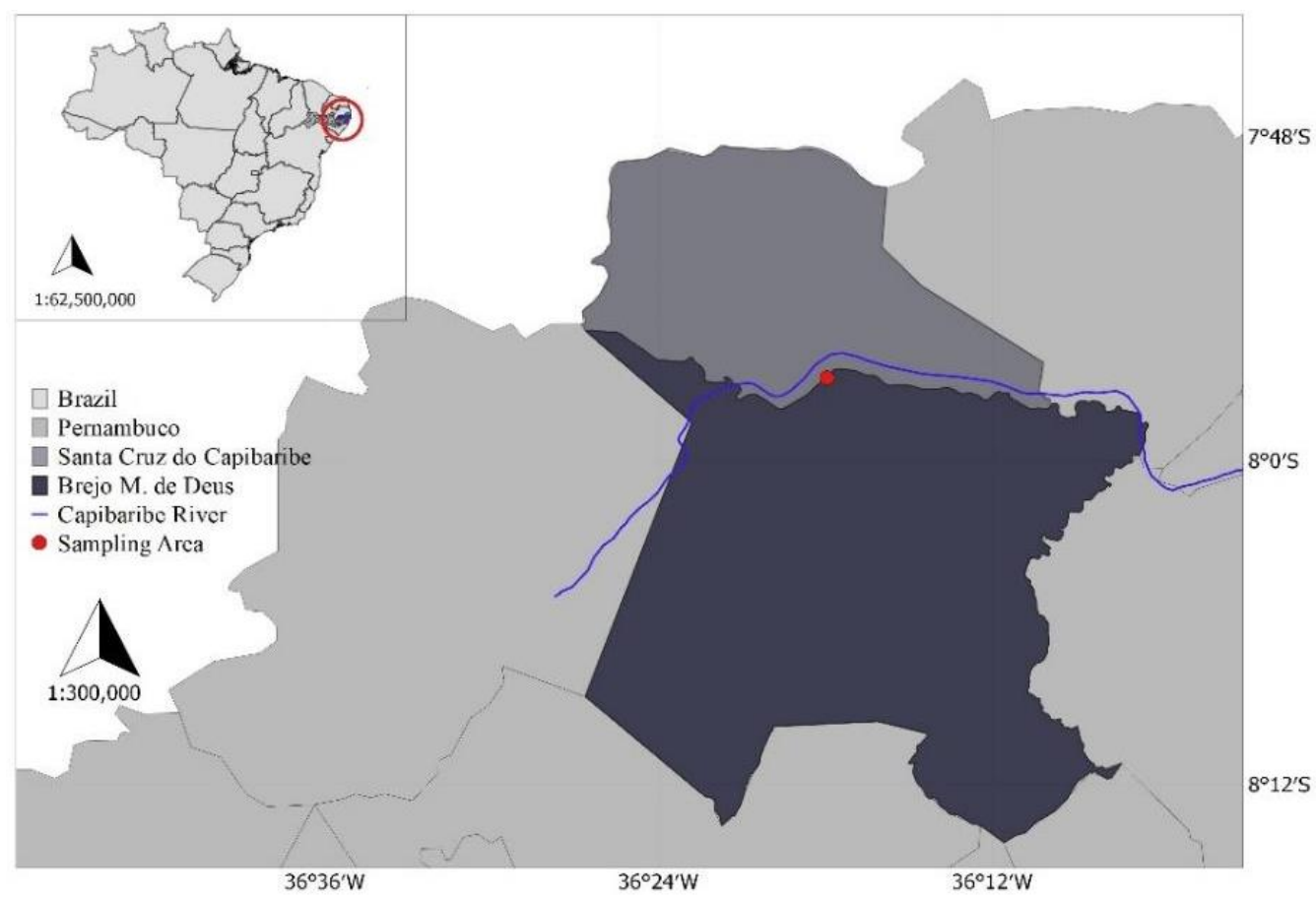

Figure 1. Location of the cities of Brejo da Madre de Deus and Santa Cruz do Capibaribe.

\subsection{Physical and Chemical Properties of Soils}

Batch experiments were performed with soil samples collected at two depths of the alluvial deposits. The first soil belongs to the most superficial layer (Layer 1), with a thickness of approximately $50 \mathrm{~cm}$. The second soil belongs to the subsequent layer (Layer 2), which is about $60 \mathrm{~cm}$ thick. Some physicochemical properties of these soils were determined by Rabelo (2018), and are presented in Table 1.

According to Table 1, Layer 1 (superficial) has higher clay $(7.03 \%)$ and organic matter $(2.17 \%)$ contents than Layer 2, which presented a clay portion of $2.34 \%$. These soils were classified as Loamy Sand and Sand, respectively. Vimonses et al. (2009) and Yagub et al. (2014) verified that information about the clay content in sorption studies is essential because this characteristic can influence the sorption of the $\mathrm{DB} 22$ dye. The $\mathrm{pH}$ values in $\mathrm{H}_{2} \mathrm{O}$ were higher than the $\mathrm{pH}$ in $\mathrm{KCl}$. These results are attributed to the effect of the $\mathrm{KCl}$ solution, which, in contact with the soil, induces cation exchange, with consequent increase of acidity (Plieski et al., 2004; Ebeling et al., 2008). Layer $1\left(3.75 \mathrm{~m}^{2} . \mathrm{g}^{-1}\right)$ has a specific surface greater than Layer 
$2\left(2.56 \mathrm{~m}^{2} \cdot \mathrm{g}^{-1}\right)$. The iron $(\mathrm{Fe})$ content in Layer 1 was higher than in Layer 2 . This element can be presented in different phases and, consequently, with varying states of oxidation. Studies such as Siqueira et al. (2008) and Parsa and Chianeh (2012) prove the use and efficiency of iron oxide compounds in textile dye adsorption. In terms of silicon and aluminum oxides, they facilitate electrostatic attraction and cation exchange between the soil and the dye molecule (Freitas et al., 2015).

Table 1. Particle-size distribution and soil classification.

\begin{tabular}{|c|c|c|c|}
\hline Physicochemical Properties & & Layer 1 & Layer 2 \\
\hline Clay $(\%)$ & & 7.03 & 2.34 \\
\hline Silte $(\%)$ & & 10.55 & 3.52 \\
\hline Sand $(\%)$ & & 82.42 & 94.14 \\
\hline Textural class & & Loamy Sand & Sand \\
\hline Organic Carbon average $\left(\mathrm{g} . \mathrm{g}^{-1}\right)$ & & $1.26 \%$ & $0.97 \%$ \\
\hline Organic Matter average (g. $\left.\mathrm{g}^{-1}\right)$ & & $2.17 \%$ & $1.67 \%$ \\
\hline Specific Surface $\left(\mathrm{m}^{2} \cdot \mathrm{g}^{-1}\right)$ & & 3.75 & 2.46 \\
\hline $\mathrm{pH}$ water & & 8.26 & 6.00 \\
\hline $\mathrm{pH} \mathrm{KCl}$ & & 6.87 & 5.48 \\
\hline \multirow{6}{*}{ Exchangeable Bases $\left(\mathrm{cmolc} / \mathrm{dm}^{-3}\right)$} & $\mathrm{Ca}$ & 2.70 & 0.75 \\
\hline & $\mathrm{Mg}$ & 1.80 & 1.25 \\
\hline & $\mathrm{Na}$ & 2.40 & 0.62 \\
\hline & $\mathrm{K}$ & 0.10 & 0.07 \\
\hline & $\mathrm{Al}$ & 0.00 & 0.00 \\
\hline & $\mathrm{H}$ & 0.41 & 0.57 \\
\hline Sum of Bases $\left(\mathrm{cmolc} / \mathrm{dm}^{-3}\right)$ & & 7.0 & 2.7 \\
\hline Cation Exchange Capacity $\left(\mathrm{cmolc} / \mathrm{dm}^{-3}\right)$ & & 7.4 & 3.3 \\
\hline Saturation of Bases (\%) & & 94 & 83 \\
\hline $\mathrm{Fe}\left(\mathrm{mg} \cdot \mathrm{kg}^{-1}\right)$ & & $13897 \pm 445$ & $7928 \pm 443$ \\
\hline $\mathrm{Al}\left(\mathrm{mg} \cdot \mathrm{kg}^{-1}\right)$ & & $64760 \pm 1852$ & $58802 \pm 1847$ \\
\hline $\mathrm{Si}\left(\mathrm{mg} \cdot \mathrm{kg}^{-1}\right)$ & & $384913 \pm 11468$ & $416429 \pm 11468$ \\
\hline
\end{tabular}

\subsection{Point of Zero Charge}

The surface charge of both soil layers was evaluated to define the $\mathrm{pH}$ value at which the adsorption of ions that determine $\mathrm{H}^{+}$and $\mathrm{OH}^{-}$potential is the same without interfering in the specific $\mathrm{pH}$ range of the environment. The methodology for the determination of the Point of Zero Charge (PZC) followed the recommendation proposed by Regalbuto and Robles (2004). The $\mathrm{pH}$ range where PZC occurred was used as an experimental adjustment parameter in the sorption experiments.

\subsection{Direct Black 22}

The dye used for this study was Direct Black 22 (DB22, CAS 6473-13-8), which was chosen because it is widely used by the textile industries of the Confection Center in Pernambuco's Agreste (Amorim et al., 2013). Direct Black 22 is suitable for dyeing cellulosic fibers such as cotton, wool, viscose, rayon, and paper. It has the appearance of black powder and water solubility of 40 g.L. $\mathrm{L}^{-1}$ (at $90^{\circ} \mathrm{C}$ ). Its molecular structure can be seen in Figure 2; molecular weight is $1083,97 \mathrm{~g} \cdot \mathrm{mol}^{-1}$, and melting point is higher than $360^{\circ} \mathrm{C}$. The DB22 used in this study is from Henan Coreychem Co., Ltd, with $98 \%$ purity, and it was manufactured in China. 


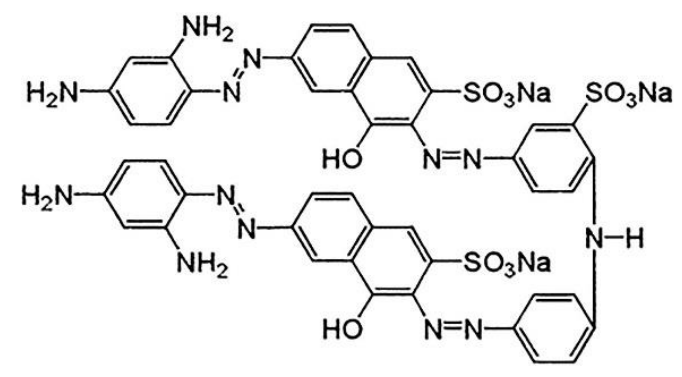

Figure 2. Molecular Structure of Direct

Black 22.

\subsection{Preparation of hydrolyzed dye}

The DB22 solution was prepared with $65 \mathrm{mg}$ of the dye diluted in $2 \mathrm{~L}$ of distilled water and was hydrolyzed according to Santos (2012) methodology. At this stage, the initial pH of the dye solution prepared with distilled water was adjusted to 11.00 with a $20 \%(\mathrm{w} / \mathrm{v})$ concentration of the $\mathrm{NaOH}$ solution. The $\mathrm{NaOH}$ used is from the Merck company with a $98 \%$ degree of purity, and it was manufactured in Brazil. This solution was heated to $80^{\circ} \mathrm{C}$ for 60 minutes and stirred on a magnetic stirrer. At the end of this period and the solution cooling, the $\mathrm{pH}$ was adjusted until the $\mathrm{PZC}$ with $\mathrm{HCl}(0.1 \mathrm{~N})$ solution was obtained. The $\mathrm{HCl}$ used is from the Merck company with a 37\% degree of purity, and it was manufactured in Brazil. This type of hydrolysis procedure is typically used in the preparation of dyes for dyeing garments in the textile industry. Thus, this solution served to analyze the behavior of the characteristic dye solution of textile industries in the study region.

\subsection{Batch tests}

Sorption tests were performed in triplicate and were based on the method described by Martins and Mermoud (1998) and Silva Júnior et al. (2019). For the kinetic study, $50 \mathrm{ml}$ of a $32.5 \mathrm{mg} . \mathrm{L}^{-1}$ solution of DB22 and $5 \mathrm{~g}$ of soil in a $250 \mathrm{ml}$ Erlenmeyer were added. The samples were then placed in a shaking incubator and shaken for $0.25 ; 0.5 ; 1 ; 2 ; 4 ; 6 ; 8 ; 10 ; 12 ; 24 ; 48$ and 72 hours. At the end of each experiment, the supernatant liquid was filtered through 0.45 $\mu \mathrm{m}$ membranes, and DB22 concentration was determined on a UV/VIS spectrophotometer with a wavelength of $481 \mathrm{~nm}$.

The obtained data were used to calculate the amount of dye adsorbed per gram of residue, according to Equation 1.

$$
S t=\frac{C o-C e}{M}
$$

Where Co is the initial dye concentration in solution $\left(\mathrm{mg} \cdot \mathrm{L}^{-1}\right)$; $\mathrm{Ce}$ is the equilibrium concentration of the dye in solution (mg. $\left.\mathrm{L}^{-1}\right)$; V is the volume of the solution (L); $\mathrm{M}$ is the dry mass of the adsorbent in solution $(\mathrm{mg})$; St is the sorption in time $\left(\mathrm{mg} \cdot \mathrm{kg}^{-1}\right)$.

The curves resulting from the sorption kinetics were evaluated by fitting the data to the First and Second-Order models according to Equations 2 and 3, respectively (Yaneva and Koumanova, 2006).

$$
\begin{aligned}
& \log \log \left(S_{e 1}-S_{t}\right)=\log S_{e 1}-\frac{k_{1}}{2,303} t \\
& \frac{1}{S_{e 2}-S_{t}}=\frac{1}{S_{e 2}}+k_{2} t
\end{aligned}
$$

Where $S_{\mathrm{e} 1}$ is the sorption capacity in equilibrium $\left(\mathrm{mg}^{-1 g^{-1}}\right)$ and $\mathrm{k}_{1}$ is the first-order sorption constant rate $\left(\mathrm{h}^{-1}\right)$. The term $\mathrm{S}_{\mathrm{e} 2}$ is the second-order sorption capacity in equilibrium $\left(\mathrm{mg} \cdot \mathrm{kg}^{-1}\right)$ and $\mathrm{k}_{2}$ is the second-order sorption constant rate $\left(\mathrm{kg} \cdot \mathrm{mg}^{-1} \cdot \mathrm{h}^{-1}\right)$. 
After defining the equilibrium time in the kinetic study, sorption isotherm experiments were performed to evaluate sorption capacity as a function of dye concentration. Samples were prepared in the same way as for sorption kinetics. DB22 concentrations used for this experiment were $1 ; 5 ; 10 ; 15 ; 20 ; 32.5$ and 40 in $\mathrm{mg} . \mathrm{L}^{-1}$. The isotherm mathematical models used were the linear, Langmuir and Freundlich. These equations are efficient in determining the parameters of dye sorption in the soil (Caliman et al., 2009). The Linear, Langmuir and Freundlich models are presented in Equations 4, 5 and 6, respectively.

$S=K_{D} C_{e}$

$S=\frac{K_{L} S_{0} C_{e}}{1+K_{L} C_{e}}$

$S=K_{F} C_{e}^{1 / n}$

Where $\mathrm{S}$ is the amount of dye adsorbed in $\mathrm{mg} \cdot \mathrm{kg}^{-1}$ of soil, Ce is the dye concentration in the equilibrium solution (mg. $\mathrm{L}^{-1}$ ), $\mathrm{K}_{\mathrm{D}}$ is the soil-solution partition constant expressed in $\mathrm{L}_{\mathrm{kg}} \mathrm{kg}^{-1}$; $\mathrm{K}_{\mathrm{L}}$ represents the Langmuir constant expressed in $\mathrm{L} \mathrm{mg}^{-1}, \mathrm{~S}_{0}$ is the maximum sorption capacity in mg. $\mathrm{kg}^{-1}, \mathrm{~K}_{\mathrm{F}}$ is the Freundlich's constant expressed in $\left(\mathrm{kg}^{-1} \mathrm{mg}^{1-1 / n} \mathrm{~L}^{1 / \mathrm{n}}\right)$, and $n$ is a dimensionless parameter.

\section{RESULTS AND DISCUSSION}

\subsection{Point of Zero Charge}

The determination of the PZC value is an essential step in this study. This information will assist in adjustments in the solutions' pH during the batch test. Studies such as Lucena (2018) prove the influence of this electrokinetic characteristic on dye sorption. The results of the point of zero charge (PZC), which was 5.02 for Layer 1 and 6.05 for Layer 2, indicate that the $\mathrm{pH}$ is acidic for both soils.

\subsection{Sorption Kinetics}

Sorption kinetics tests provide valuable insight into the behavior of dye sorption in soils. First and second-order kinetic models were used to help understand the behavior of the interaction between the pollutant and the solid soil matrix. The results of DB22 sorption kinetics for both soils can be seen in Figure 3.
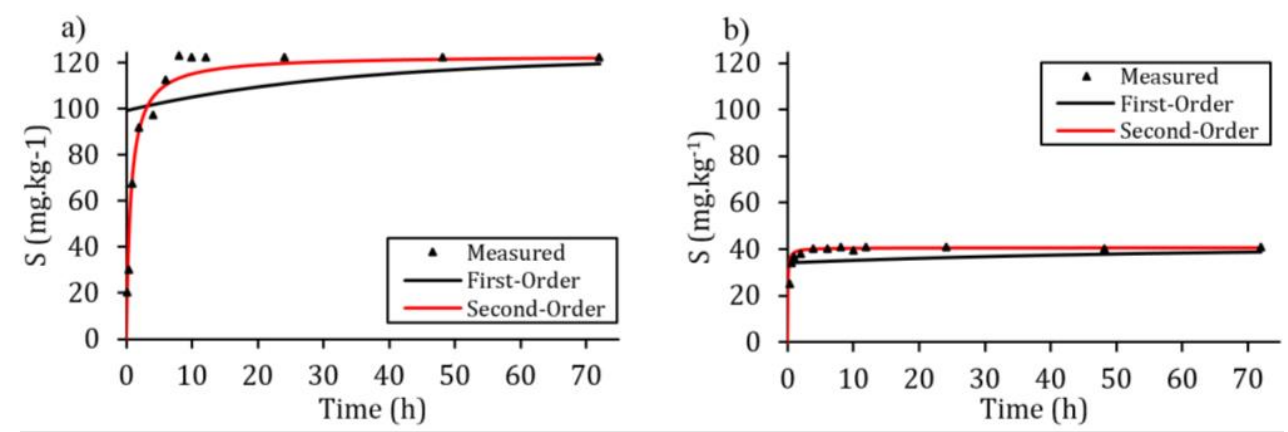

Figure 3. Sorption kinetics curve of the studied soils: a) Layer 1; b) Layer 2.

According to the results of sorption kinetics in Figure 3, Layer 1 required 8 hours to reach equilibrium and adsorbed approximately $120 \mathrm{mg}$ of DB22 per $\mathrm{kg}$ of soil. Layer 2 achieved equilibrium in about $4 \mathrm{~h}$, and during this time, adsorbed approximately $40.86 \mathrm{mg} \cdot \mathrm{kg}^{-1}$. Layer 1 therefore presents more sorption sites, which, according to Yagub et al. (2014), increases dye 
sorption, and so adsorption on Layer 1 was thereby higher.

According to the obtained equilibrium times, it is possible to consider the dye sorption as an instantaneous phenomenon, in which chemical equilibrium is quickly reached. This consideration is based on kinetic studies in which equilibrium is achieved within no more than 24 hours (Bukallah et al., 2007; Hong et al., 2014; Dawodu and Akpomie, 2016). Regarding the equilibrium time, the results are in agreement with what is presented by Caliman et al. (2009), who concluded that the stirring time of 8 hours is the most appropriate to obtain the adsorption of an azo dye in a soil that has similar particle-size characteristics as the studied soil. Albanis et al. (2000) observed slower sorption, between 4 and 6 hours, for an azo dye in fly ash mixtures on a soil of low organic-matter content.

These results indicate that DB22 has a higher potential to be sorbed in Layer 1 than in Layer 2. This phenomenon can be explained by the higher presence of clay in Layer $1(7.03 \%)$ than in Layer $2(2.34 \%)$, and because the textile dye has a high ability to interact chemically with minerals in the soil (Duarte-Neto et al., 2014; Santori et al., 2011; Souza et al., 2016). According to Table 1, Layer 1 has a higher OM content (2.17\%) than Layer 2, resulting in a potentially higher reactivity between the soil and the DB22. According to Linhares et al. (2010), $\mathrm{OM}$ is a factor that influences the higher sorption of organic substances.

First-order kinetic model values were obtained from a linear regression between $\ln \left(\mathrm{S}_{\mathrm{e}}-\mathrm{S}_{\mathrm{t}}\right)$ by time (h). Regression coefficients for the first-order kinetic model were 0.39 and 0.12 for Layer 1 and Layer 2, respectively (Table 2). These low values demonstrated that DB22 sorption for the studied soils does not follow the first-order kinetic model.

The plots of $\mathrm{t} / \mathrm{St}$ as a function of time (h) for the DB22 sorption with the soils of both layers at a concentration of $32.5 \mathrm{mg} . \mathrm{L}^{-1}$ resulted in straight lines. Regression coefficients were higher than 0.999 for both soils (Table 2). This result indicates that the sorption kinetics of DB22 follow the second-order kinetic model.

Table 2. Kinetic parameters adjusted for the First and Second-order models for both soil layers.

\begin{tabular}{|c|c|c|c|c|c|c|}
\hline \multirow[t]{2}{*}{ Soil } & \multicolumn{3}{|c|}{ First-order model } & \multicolumn{3}{|c|}{ Second-order model } \\
\hline & $\begin{array}{c}\mathrm{S}_{\mathrm{e} 1} \\
\left(\mathrm{mg} \cdot \mathrm{kg}^{-1}\right)\end{array}$ & $\begin{array}{c}\mathrm{k}_{1} \\
\left(\mathrm{~h}^{-1}\right)\end{array}$ & $r^{2}$ & $\begin{array}{c}\mathrm{S}_{\mathrm{e} 2} \\
\left(\mathrm{mg} \cdot \mathrm{kg}^{-1}\right)\end{array}$ & $\begin{array}{c}\mathrm{k}_{2} \\
\left(\mathrm{~kg} \cdot \mathrm{mg}^{-1} \cdot \mathrm{h}^{-1}\right)\end{array}$ & $\mathrm{r}^{2}$ \\
\hline Layer 1 & 23.17 & 0.0295 & 0.3955 & 123.4568 & 0.011511 & 0.9996 \\
\hline Layer 2 & 5.7902 & 0.0191 & 0.1249 & 40.6504 & 0.2420 & 0.9998 \\
\hline
\end{tabular}

The sorption capacities' values in equilibrium corroborate the higher sorption affinity of DB22 with Layer 1 because for both adjusted models the values of $S_{\mathrm{e} 1}$ and $S_{\mathrm{e} 2}$ were higher. Qu et al. (2008) and Caliman et al. (2009) also noticed similar results in their studies with azo dyes, where the second-order model represented the process more faithfully. They found $\mathrm{S}_{\mathrm{e} 2}$ equal to 281 and $224 \mathrm{mg} \cdot \mathrm{kg}^{-1}$, respectively. The summary of the parameters obtained from the adjustments of the First and Second-Order kinetic models for the DB22 kinetics data and the studied soils are presented in Table 2 .

\subsection{Sorption Isotherms}

Sorption isotherms are extremely important in the determination of maximum adsorption capacity of the studied soils, and in understanding the nature of the sorption process. The curves of DB22 sorption isotherms for the studied soils are presented in Figure 4. This study used Linear, Langmuir and Freundlich isotherm models to adjust the experimental data.

The adjustment of the isotherm to the Linear model is obtained from the regression between $S_{t}$ and $C_{e}$, which resulted in linear regression coefficients of 0.99 for Layer 1 and 0.97 for Layer 2. This indicates that this Sorption isotherm model is suitable for both soils. $K_{D}$ value 
for Layer 1 was $5.28 \mathrm{~L} . \mathrm{kg}^{-1}$, and for Layer 2 was $0.99 \mathrm{~L} . \mathrm{kg}^{-1} . \mathrm{K}_{\mathrm{D}}$ is a parameter often related to pollutant mobility in the soil and/or sediment. High $\mathrm{K}_{\mathrm{D}}$ values indicate strong sorption and low values indicate weak interaction between the dye molecule and the solid matrix surface. Thus, low $K_{D}$ values indicate high mobility and contamination risk of the surface and groundwater by leaching. Analyzing the $\mathrm{K}_{\mathrm{D}}$ of the studied soils, Layer 1 has a higher ability to retain DB22, and Layer 2 has a higher leaching potential.
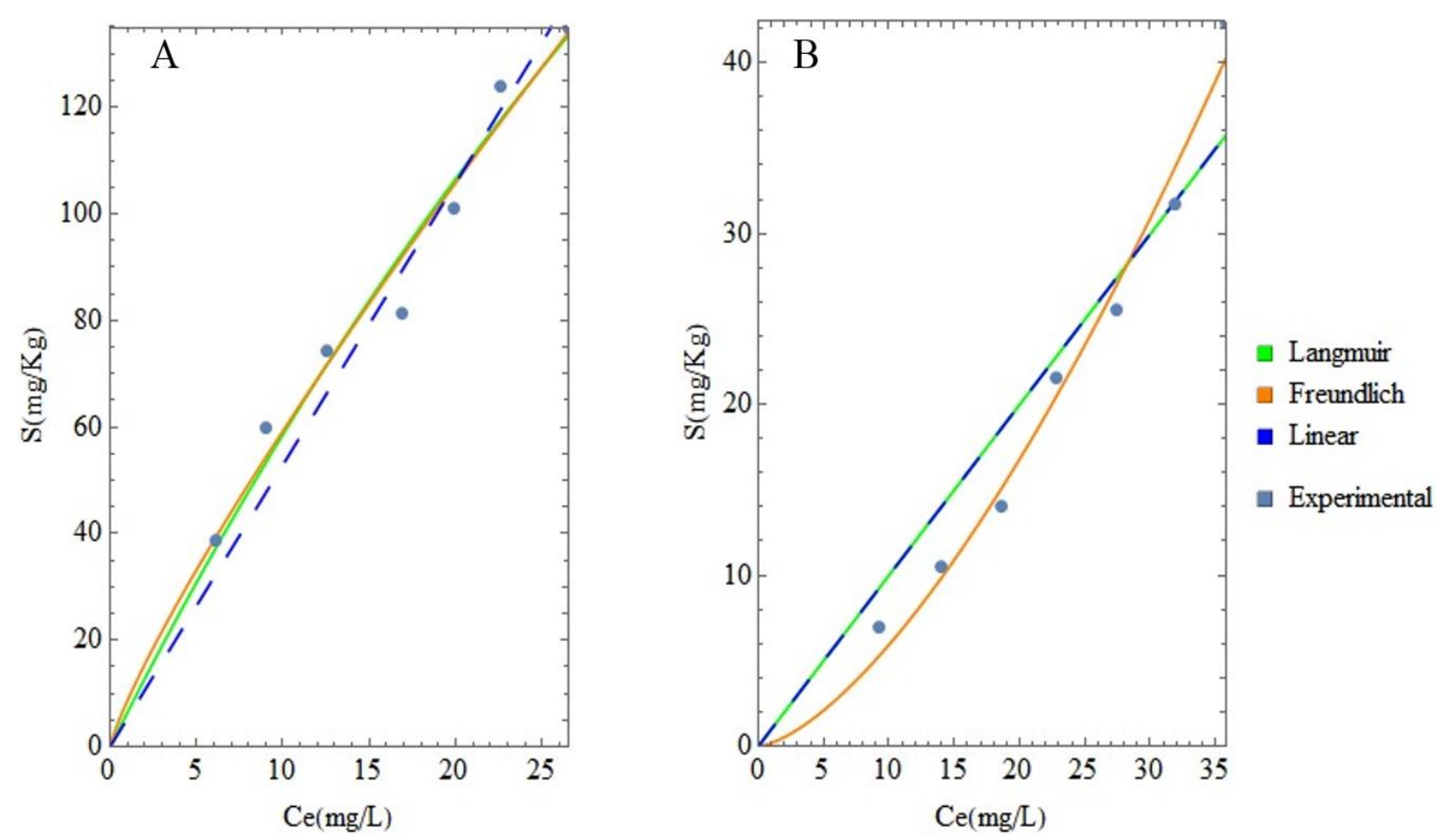

Figure 4. Langmuir, Freundlich, and Linear model adjustments for Layer 1 (A) and Layer 2 (B).

Analogous results were also found by Bukallah et al. (2007) and Dawodu and Akpomie (2016) in analyses performed with dye and soil with particle-size characteristics similar to the ones presented in this study. According to Ribeiro et al. (2007), most processes that cause contaminant attenuation in groundwater are more active in the biologically active soil zone, as a result of their higher clay and organic matter content.

Analyzing Figure 4, it is observed that the isotherms are better adjusted to the Freundlich model. The Langmuir model reasonably represents the experimental data of Layer 1, but it does not characterize Layer 2 well. The parameters of the linear, Freundlich, and Langmuir models are shown in Table 3. The values of the determination coefficients $\left(\mathrm{r}^{2}\right)$ of the Freundlich model for both layers are greater than 0.99 . Therefore, the best adjustments of the experimental data for Layers 1 and 2 resulted from the application of the Freundlich model, as verified by Bukallah et al. (2007), Qu et al. (2008), and Dawodu and Akpomie (2016). The $\mathrm{K}_{\mathrm{F}}$ values (Table 3) were $8.64\left(\mathrm{~kg}^{-1} \mathrm{mg}^{1-1 / n} \mathrm{~L}^{1 / \mathrm{n}}\right)$ and $0.18\left(\mathrm{~kg}^{-1} \mathrm{mg}^{1-1 / n} \mathrm{~L}^{1 / \mathrm{n}}\right)$ for Layers 1 and 2 , respectively. The sorption capacity of DB22 is strongly correlated with the organic matter content and clay fraction, which contributes to the DB22 sorption, as these values are quantitatively higher in Layer 1 . This finding agrees with Ketelsen and Meyer-Windel (1999), and Qu et al. (2008), who reported a positive correlation between the studied dyes and the soil clay content. Regarding $\mathrm{K}_{\mathrm{F}}$ values, the results agree with other studies conducted with azo dyes such as Qu et al. (2008) and Uğurlu (2009).

Caliman et al. (2009), Morris et al. (2008), and Germán-Heins and Flury (2000) performed the adjustments according to Langmuir models for isotherms of a system composed of an azo dye and sandy soil. These authors obtained $\mathrm{K}_{\mathrm{L}}\left(\mathrm{L}_{\mathrm{mg}} \mathrm{mg}^{-1}\right)$ of $0.00365,0.0124$ and 0.0157, 
respectively. The low values indicate that the binding energy between sandy soils and dyes of the same type as DB22 is weak, indicating high mobility.

Table 3. Langmuir and Freundlich isotherms parameters for the alluvial soil's layers of the Capibaribe River dry bed.

\begin{tabular}{cccc}
\hline Models & & Layer 1 & Layer 2 \\
\hline \multirow{2}{*}{ Linear } & $\mathrm{K}_{\mathrm{D}}\left({\left.\mathrm{L} . \mathrm{kg}^{-1}\right)}^{2}\right.$ & 5.286672 & 0.999598 \\
& $\mathrm{r}^{2}$ & 0.993927 & 0.979776 \\
Freundlich & $\mathrm{K}_{\mathrm{F}}\left(\mathrm{kg}^{-1} \mathrm{mg}^{1-1 / \mathrm{n}} \mathrm{L}^{1 / \mathrm{n}}\right)$ & 8.640709 & 0.186793 \\
& $\mathrm{n}$ & 0.836228 & 1.501927 \\
& $\mathrm{r}^{2}$ & 0.996656 & 0.996152 \\
Langmuir & $\mathrm{K}_{\mathrm{L}}\left({\left.\mathrm{L} . \mathrm{mg}^{-1}\right)}\right.$ & 0.011056 & $6.67 \mathrm{E}-05$ \\
& $\mathrm{~S}_{0}$ & 588.2885 & 15008.5 \\
& $\mathrm{r}^{2}$ & 0.996125 & 0.979655 \\
\hline
\end{tabular}

\section{CONCLUSIONS}

A second-order model best described the sorption kinetics of DB22, and the Freundlich and Linear models properly adjusted the sorption isotherms for Layers 1 and 2. The organic matter content and the cation exchange capacity of both soil layers influenced the dye sorption. The superficial layer privileges dye retention phenomena while the subsurface layer favors dye mobility.

\section{ACKNOWLEDGMENTS}

This work was carried out with the support of the project "Transfer of Water and Mixtures of Reactive Pollutants in Anthropized Soils" (CNPq process No. 436875/2018-7) and of the project "National Observatory of Water and Carbon Dynamics in the Caatinga Biome ONDACBC (CNPq process $\mathrm{N}^{\circ} 465764 / 2014-2$; CAPES process $\mathrm{N}^{\circ} 88887.136369 / 2017-00$; FACEPE process APQ-0498-3.07/17).

\section{REFERENCES}

ALBANIS, T. A.; HELA, D. G.; SAKELLARIDES, T. M.; DANIS, T. G. Removal of dyes from aqueous solutions by adsorption on mixtures of fly ash and soil in batch and column techniques. Global NEST Scientific Environmental Journal, v. 2, n. 3, p. 237-244, 2000 .

ALI, N.; HAMEED, A.; AHMED, S. Physicochemical characterization and bioremediation perspective of textile effluent, dyes and metals by indigenous bacteria. Journal of $\begin{array}{llllll}\text { Hazardous Materials, } & \text { v. } & 164, & \text { p. } & 322-328, & \end{array}$ https://doi.org/10.1016/j.jhazmat.2008.08.006

ALVES, A. T. A.; SILVA, L. T. M. S.; ALCÂNTARA, L. R. P.; BARROS, V. H. O.; SANTOS NETO, S. M.; LIMA, V. F.; ARTUR P. C.; ANTONINO, A. C. D. Sorption of Remazol Black B dye in alluvial soils of the Capibaribe River Basin, Pernambuco, Brazil. Revista Ambiente \& Água, v. 15, n. 2, p. 1-12, 2020. https://doi.org/10.4136/ambi-agua.2491 
AMORIM, S. M.; KATO, M. T.; FLORENCIO, L. Influence of Redox Mediators and Electron Donors on the Anaerobic Removal of Color and Chemical Oxygen Demand from Textile Effluent. CLEAN-Soil, Air, Water, v. 41, p. 928-933, 2013. https://doi.org/10.1002/clen.201200070

BELTRÃO, B. A.; MASCARENHAS, J. de C.; MIRANDA, J. L. F. de; SOUZA JUNIOR, L. C. de; GALVÃO, M. J. da T. G.; PEREIRA, S. N. (Orgs.). Projeto cadastro de fontes de abastecimento por água subterrânea: estado de Pernambuco: diagnóstico do município de Santa Cruz do Capibaribe. Recife: CPRM, 2005. 10p. 1 mapa.

BRAGA, R. A. P.; FARIAS, C. R. O.; SILVA, S. R.; CAVALCANTE, E. R. Gestão e Educação Socioambiental na Bacia do Capibaribe. 1. ed. Recife: Ed. Clã, 2015. 144p.

BRITO, G. L. M.; COUTINHO, A. P.; CABRAL, J. J. D. S. P.; SANTOS NETO, S. M. D.; ANTONINO, A. C. D.; CIRILO, J. A.; SILVA FILHO, S. L. D. Characterization of the Capibaribe River Dry Bed with Ground Penetrating Radar (GPR). Revista Brasileira de Brasileira de Recursos Hídricos, v. 23, 2018. https://doi.org/10.1590/23180331.0318170023

BUKALLAH, S. B.; RAUF, M. A.; ALALI, S. S. Removal of Methylene Blue from aqueous solution by adsorption on sand. Dyes and Pigments, v. 74, p. 85-87, 2007. https://doi.org/10.1016/j.dyepig.2006.01.016

CALIMAN, F. A.; APOSTOL, L.; BULGARIU, D.; BULGARIU, L. Sorption of Acid Yellow 23 from aqueous solutions onto soil. Afinidad, v. 544, p. 465-473, 2009.

DAWODU, M. O; AKPOMIE, K. G. Evaluating the potential of a Nigerian soil as an adsorbent for tartrazine dye: Isotherm, kinetic and thermodynamic studies. Alexandria $\begin{array}{llllll}\text { Engineering Journal, } & \text { v. } & 4, & \text { p. } & 3211-3218,\end{array}$ https://doi.org/10.1016/j.aej.2016.08.008

DUARTE-NETO, J. F. et al. Processos de adsorção de corantes em argilas esmectíticas: uma revisão. Revista Eletrônica de Materiais e Processos, v. 9, n. 1, p. 51-59, 2014.

EBELING, A. G.; ANJOS, L. H. C.; PÉREZ, D. V.; PEREIRA, M. G.; VALLADARES, G. S. Relação entre acidez e outros atributos químicos em solos com teores elevados de matéria orgânica. Bragantia, v. 67, n. 2, p. 429-439, 2008. https://doi.org/10.1590/S000687052008000200019

FREITAS, F. B. A.; CÂMARA, M. Y. F.; MARTINS, D. F. F. Determinação do PCZ de adsorventes naturais utilizados na remoção de contaminantes em soluções aquosas. Blucher Chemistry Proceedings, v. 3, n. 1, p. 1-8, 2015. https://dx.doi.org/10.5151/chenpro-5erq-am1

GERMÁN-HEINS, J.; FLURY, M. Sorption of Brilliant Blue FCF in soils as affected by $\mathrm{Ph}$ and ionic strength. Geoderma, v. 97, p. 87-101, 2000. https://doi.org/10.1016/S00167061(00)00027-6

GRACIANI, F. S. Contaminantes emergentes: Azocorantes e PBTAs. Revista Espacios, v. 35, n. 6, p. 1-7, 2014.

HONG, J. et al. Synthesis of pore-expanded mesoporous materials using waste quartz sand and the adsorption effects of methylene blue. Journal of Industrial and Engineering Chemistry, v. 30, p. 30-35, 2014. https://doi.org/10.1016/j.jiec.2013.12.064 
KETELSEN, H.; MEYER-WINDEL, S. Adsorption of brilliant blue FCF by soils. Geoderma, v. 90, n. 1-2, p. 131-145, 1999, https://doi.org/10.1016/S0016-7061(98)00119-0

KONICKI, W.; ALEKSANDRZAK, M.; MOSZYŃSKI, D.; MIJOWSKA, E. Adsorption of anionic azo-dyes from aqueous solutions onto graphene oxide: equilibrium, kinetic and thermodynamic studies. Journal of colloid and interface science, v. 496, p. 188-200, 2017. https://doi.org/10.1016/j.jcis.2017.02.031

LINHARES, L. A.; EGREJA FILHO, F. B.; BELLIS, V. M.; SANTOS, E. A.; IANHEZ, R. Utilização dos modelos de Langmuir e de Freundlich na adsorção de cobre e zinco em solos brasileiros. Acta Agronômica, v. 59, n. 3, p. 303-315. 2010.

LUCENA, L. M. Estudo do processo de adsorção com o carvão ativado proveniente do endocarpo de coco (COCCUS NUCIFERA L.) para remoção de cor, DQO e toxicidade de efluente têxtil. 2018. Dissertação (Mestrado) - Universidade Federal de Pernambuco, Programa de Pós-Graduação em Engenharia Civil e Ambiental, Caruaru, 2018.

MARTINS, J. M. F.; MERMOUD, A. Sorption and biodegradation of four nitroaromatic herbicides in mono and multi-solute saturated/unsaturated soil batch systems. Journal of Contaminant Hydrology, v. 3, p. 187-210, 1998. https://doi.org/10.1016/S01697722(98)00070-9

MONTAGNER, C. C.; VIDAL, C.; ACAYABA, R. D. Contaminantes emergentes em matrizes aquáticas do brasil: cenário atual e aspectos analíticos, ecotoxicológicos e regulatórios. Química Nova, v. 40, n. 9, p. 1094-1110, 2017. https://doi.org/10.21577/01004042.20170091

MORRIS, C.; MOONEY, S. J.; YOUNG, S. D. Sorption and desorption characteristics of the dye tracer, Brilliant Blue FCF, in Sandy and clay soils. Geoderma, v. 146, p. 434-438, 2008. https://doi.org/10.1016/j.geoderma.2008.06.021

MUNAGAPATI, V. S.; WEN, J. C.; PAN, C. L.; GUTHA, Y.; WEN, J. H. Enhanced adsorption performance of Reactive Red 120 azo dye from aqueous solution using quaternary amine modified orange peel powder. Journal of Molecular Liquids, v. 285, p. 375-385, 2019. https://doi.org/10.1016/j.molliq.2019.04.081

NAZIR, R.; KHAN, M.; REHMAN, R. U.; SHUJAH, S.; KHAN, M.; ULLAH, M.; AHMAD, I. Adsorption of selected azo dyes from an aqueous solution by activated carbon derived from Monotheca buxifolia waste seeds. Soil and Water Research, v. 15, p. 166-172, 2020. https://doi.org/10.17221/59/2019-SWR

OLIVEIRA, R. V.; BRAGA, B. M. Território comercial de Toritama: persistência e metamorfoses da informalidade. Revista de Ciências Sociais, n. 41, p. 193-225, 2014.

PARSA, J. B.; CHIANEH, F. N. Evaluation of electro-coagulation method for decolorization and degradation of organic dyes in aqueous solutions. Korean Journal of Chemical Engineering, v. 29, p. 1585-1590, 2012. https://doi.org/10.1007/s11814-012-0065-5

PLIESKI, G. L. A.; EBELING, A. G.; ANJOS, L. H. C.; PEREIRAM, M. G.; VALLADARES, G. S. Avaliação de métodos analíticos para determinar acidez em solos com alto teor de matéria orgânica. Revista Universidade Rural: Série Ciências da Vida, v. 24, n. 2, p. $15-21,2004$. 
QU, B.; ZHOU, J.; XIANG, X.; ZHENG, C.; ZHAO, H.; ZHOU, X. Adsorption behavior of azo ye C.I. Acid Red 14 in aqueous solution on surface soils. Journal of Environmental Sciences, v. 20, p. 704-709, 2008. https://doi.org/10.1016/S1001-0742(08)62116-6

RABELO, A. E. C. G. Retenção e mobilidade da Sulfadiazina em um aluvionar do Alto do Capibaribe. 2018. Dissertação (Mestrado) - Universidade Federal de Pernambuco. Programa de Pós-Graduação em Tecnologias Energéticas e Nucleares, Recife, 2018.

Regalbuto, J. R.; ROBleS, J. The engineering of Pt/Carbon Catalyst Preparation. Chicago: University of Illinois, 2004.

RIBEIRO, M. L.; LOURENCETTI, C.; PEREIRA, S. Y.; MARCHI, M. R. R. Contaminação de águas subterrâneas por pesticidas: avaliação preliminar. Química Nova, v. 30, n. 3, p. 688-694, 2007. https://doi.org/10.1590/S0100-40422007000300031

SANTORI, R. A. et al. Adsorção do corante azul de metileno em partículas de argilominerais: análise dos tamanhos das partículas. Química Nova, v. 34, n. 4, p.5 84-588, 2011. http://dx.doi.org/10.1590/S0100-40422011000400006

SANTOS, B. R. T. Efeito de diferentes doadores de elétrons e da variação de concentração de sulfato na descoloração redutiva do corante direct black 22. 2012. Dissertação (Mestrado) - Universidade Federal de Pernambuco, Programa de Pós-Graduação em Engenharia Civil, Recife, 2012.

SHALABY, N. H.; EWAIS, E. M. M.; ELSAADANY R. M.; AHMED, A. Rice husk templated water treatment sludge as low cost dye and metal adsorbent. Egyptian Journal of Petroleum, v. 26, p. 661-668, 2016. https://doi.org/10.1016/j.ejpe.2016.10.006

SHEHZADI, M.; AFZAL, M.; ISLAM, E.; MOBIN, A.; ANWAR, S.; KHAN, Q. Enhanced degradation of textile effluent in constructed wetland system using Typha domingensis and textile effluent-degrading endophytic bacteria. Water Research, v. 8, p. 152-159, 2014. https://doi.org/10.1016/j.watres.2014.03.064

SILVA JÚNIOR, E. D.; COUTINHO, A. P.; SANTOS NETO, S. M.; RABELO, A. E. C. G. C.; ANTONINO, A. C. D.; LIMA, V. F.; GONDIM, M. V. S. Sorção da sulfadiazina em solo urbano: experimentação e modelagem. Águas Subterrâneas, v.33(4), p.368-377, 2019. https://doi.org/10.14295/ras.v33i4.29543

SIQUEIRA, G. F.; SCHNEIDER, DONADIA, J. F.; LELIS, M. F. F. Decomposição de corantes reativos por fotocatálise utilizando resíduo de beneficiamento de granito. In: CONGRESSO BRASILEIRO DE QUÍMICA, 48., Oct. 2008, Rio de Janeiro. Anais[...] Rio de Janeiro: CBQ, 2008. p.1-3.

SOUZA, C. F.; BASTOS, R. G.; GOMES, M. P. M.; PULSCHEN, A. A. Eficiência de estação de tratamento de esgoto doméstico visando reuso agrícola. Revista Ambiente \& Água, v. 10, n. 3, p. 587- 597, 2016. https://doi.org/10.4136/ambi-agua.1549

SOUZA, M. C. S. A.; SOUZA, G. K. A. Poluentes Emergentes: um Perigo Silencioso para o Meio Ambiente e um Desafio para as Novas Tecnologias de Informação e Comunicação. Revista Direito Público, v. 13, n. 72, p.76-90, 2016.

UĞURLU, M. Adsorption of a textile dye onto activated sepiolite. Microporous and $\begin{array}{llllll}\text { Mesoporous } & \text { Materials, } & \text { v. } & 119, & \text { p. } & \text { 276-283, }\end{array}$ https://doi.org/10.1016/j.micromeso.2008.10.024 
VIKRANT, K.; GIRI, B. S.; RAZA, N.; ROY, K.; KIM, K. H.; RAI, B. N.; SINGH, R. S. Recent advancements in bioremediation of dye: Current status and challenges. $\begin{array}{llllll}\text { Bioresource technology, } & \text { v. 253, } & \text { p. } & 355-367,\end{array}$ https://doi.org/10.1016/j.biortech.2018.01.029

VIMONSES, V.; LEI, S.; BO, J.; CHOW, C. W. K.; SAINT, C. Kinetic study and equilibrium isotherm analysis of Congo Red adsorption by clay materials. Chemical Engineering Journal, v. 148, p. 354-364, 2009. https://doi.org/10.1016/j.cej.2008.09.009

YAGUB, M. T.; SEM, T. K.; AFROZE, M.; H.M Dye and its removal from aqueous solution by adsorption: A review. Advances in Colloid and Interface Science, v. 209, p. 172184, 2014. https://doi.org/10.1016/j.cis.2014.04.002

YANEVA, Z.; KOUMANOVA, B. Comparative modeling of mono and dinitrophenols sorption on yellow bentonite from aqueous solutions. Journal of Colloid and Interface Science, v. 293, p. 303-311, 2006. https://doi.org/10.1016/j.jcis.2005.06.069 